Original Research Article

\title{
Study of anticonvulsant activity of acetazolamide on albino rats and its influence on anticonvulsant activity of sodium valproate
}

\author{
Hemanth Kumar K. H., Kishore M. S.*
}

Department of Pharmacology Mysore Medical College and Research Institute, Irwin Road, Mysuru, Karnataka 570001, India

Received: 14 March 2018 Accepted: 07 April 2018

*Correspondence to: Dr. Kishore M. S., Email: 2011hemanth@ gmail.com

Copyright: (C) the author(s), publisher and licensee Medip Academy. This is an openaccess article distributed under the terms of the Creative Commons Attribution NonCommercial License, which permits unrestricted noncommercial use, distribution, and reproduction in any medium, provided the original work is properly cited.

\begin{abstract}
Background: Epilepsy is a common neurological disorder. $30-40 \%$ of patients will continue to have seizures despite the use of antiepileptic drugs either alone or in combination. The present study is undertaken to evaluate the anticonvulsant activity of Acetazolamide (ACZ) in albino rats and its influence on anticonvulsant activity of sodium valproate.

Methods: Albino rats (150-200gms) of male sex were randomly selected, from central animal facility, MMCRI, Mysore. They were divided into 6groups (per model) of 6 rats each, control group-normal saline $0.5 \mathrm{ml}$, standard group-sodium valproate $(300 \mathrm{mg} / \mathrm{kg})$, dose $1-\mathrm{ACZ}(8.75 \mathrm{mg} / \mathrm{kg})$, dose $2-\mathrm{ACZ}(17.5 \mathrm{mg} / \mathrm{kg})$ and dose 3 -ACZ $(35 \mathrm{mg} / \mathrm{kg})$, dose $4-\mathrm{ACZ}(8.75 \mathrm{mg} / \mathrm{kg})$ with sodium valproate $(150 \mathrm{mg} / \mathrm{kg})$. The anti-convulsant activity was screened using MES model and PTZ model.

Results: Results were analysed by ANOVA followed by post hoc Fisher's LSD test. The ACZ has shown anticonvulsant activity at the dose of $17.5 \mathrm{mg} / \mathrm{kg}$ and $35 \mathrm{mg} / \mathrm{kg}$ body weight and combination of $\mathrm{ACZ} 8.75 \mathrm{mg} / \mathrm{kg}$ with sodium valproate $150 \mathrm{mg} / \mathrm{kg}$ both in MES model and PTZ model. The anticonvulsant activity of ACZ was less when compared to Sodium Valproate in both MES model and PTZ model. The anticonvulsant activity of combination, ACZ $8.75 \mathrm{mg} / \mathrm{kg}$ with Sodium valproate $150 \mathrm{mg} / \mathrm{kg}$ was comparable and more significant when compared to standard drug alone in MES model and PTZ model.

Conclusions: The ACZ has shown anticonvulsant activity in MES model and PTZ induced seizure model of epilepsy. This study has shown that ACZ potentiated the effect of sodium valproate and can be used as add on drug with sodium valproate in epilepsy.
\end{abstract}

Keywords: Acetazolamide, Epilepsy, Maximal electroshock seizure model, Nephrotoxicity, Pentylene tetrazole, Tonic hind limb extension

\section{INTRODUCTION}

Epilepsy are socially handicapping disorders and even a single seizure occurring in certain circumstances may have disastrous effect. The impact of epilepsy on every aspect of both the lives of patient and family is significant. ${ }^{1}$ Despite the massive scale of the problem and much research, epilepsy remains poorly understood. Despite more than 20 approved drugs and several nonpharmacological options, up to $30 \%$ of patients are still refractory to treatment.
Despite the introduction of several new therapeutic options in the 1990s, a significant fraction of the patients with epilepsy continue to live with uncontrolled seizures. ${ }^{2}$ There is still a need for an ideal antiepileptic agent with properties like broad spectrum activity, rapid onset of action, least side effects, good oral bioavailability and low costs. ${ }^{3}$ Contemporary anticonvulsant therapy, however, is neither universally effective nor invariably safe. Their important adverse effects include central nervous system depression, ataxia, megaloblastic anaemia, cardiac arrhythmias, hepatic dysfunction and teratogenicity. ${ }^{4}$ 
Although most people with epilepsy become seizure free with appropriate therapy, $30-40 \%$ of patients will continue to have seizures despite the use of antiepileptic drugs either alone or in combination. Discovery and development of anti-epileptic drugs has been especially difficult, because of the regulatory issues of satisfactorily proving safety and efficacy, ethical constraints on placebo-controlled trial designs. For this reason known antiepileptic drugs are used in combination for the treatment. ${ }^{5}$

As the drug acetazolamide has got anti convulsive activity, this drug can be tried to use as a $2^{\text {nd }}$ line of drug in the treatment of epilepsy. As this drug is cheap and easily available, this helps peoples of developing countries like India. Many physicians and studies believe that acetazolamide can be used as a $2^{\text {nd }}$ line drug. But this drug is not receiving enough identification as anti-epileptic. As most cases of epilepsy is treated by multidrug regimens, acetazolamide can be used as add on drug with $1^{\text {st }}$ line drugs. Hence this study has been taken up to evaluate anti convulsive activity of acetazolamide.

\section{METHODS}

\section{Materials}

\section{Chemicals}

- Sodium valproate-Obtained from Sun pharmaceuticals, dissolved in Normal saline, given at the dose of $300 \mathrm{mg} / \mathrm{kg}^{11}$ body wt intraperitonially.

- Pentylene tetrazole-Obtained from Sigma Aldrich chemical corporation Bangalore, dissolved in Normal saline, given at the dose of $80 \mathrm{mg} / \mathrm{kg}^{12}$ body wt intraperitonially.

- Acetazolamide-Obtained from Wyeth limited, dissolved in Normal saline. Dose used was $8.75 \mathrm{mg} / \mathrm{kg}, 17.5 \mathrm{mg} / \mathrm{kg}, 35 \mathrm{mg} / \mathrm{kg}$ per body wt. $^{13}$

- $\quad$ Normal saline.

Animals: Male Swiss Albino rats

Equipment: Electro-convulsiometer with accessories, $1 \mathrm{ml}$ Tuberculin syringe, Electronic weighing balance, Animal weighing balance.

\section{Animals}

Seventy-two adult healthy male albino rats of wistar strain of similar characteristics weighing 150-200gms were selected from the central animal facility, MMCRI, Mysore. The above test animals were divided into two groups MES and PTZ model.

\section{Maximal electroshock seizure model (MES)}

The most commonly used simple model for evaluation of drugs useful in generalized seizures is the electroshock model, which has been validated both clinically and electroencephalographically (1952). ${ }^{6}$ MES model evaluates the ability of drugs to prevent electrically induced tonic hind limb extension (THLE) in mice or rats. Efficacy of drugs in this model correlate with their ability to prevent partial and generalized tonic clonic seizures in man.

\section{Procedure}

Adult albino male rats (150-200gms) are used. Six animals per drug dose/ vehicle are normally used. All animals are maintained on an adequate diet and allowed free access to food and water, except during testing. Stimulation is carried out through transauricular electrodes (applied to the pinna with small crocodile clips covered with cotton wool and saline-moistened) are used. Maximal seizures are evoked by supramaximal electroshock stimulation of $150 \mathrm{~mA}, 50 \mathrm{HZ}$, for 0.2 seconds by using conventional electroconvulsiometer (Figure 1). The parameters studied in MES methods were

- Tonic hind limb flexion.

- Tonic hind limb extension (Figure 2).

- Clonus.

- Stupor ((Unconsciousness) from the end of clonus to regain consciousness)

- Post ictal depression (from the regain of consciousness till the animals starts walking) duration of each parameters was recorded in seconds.

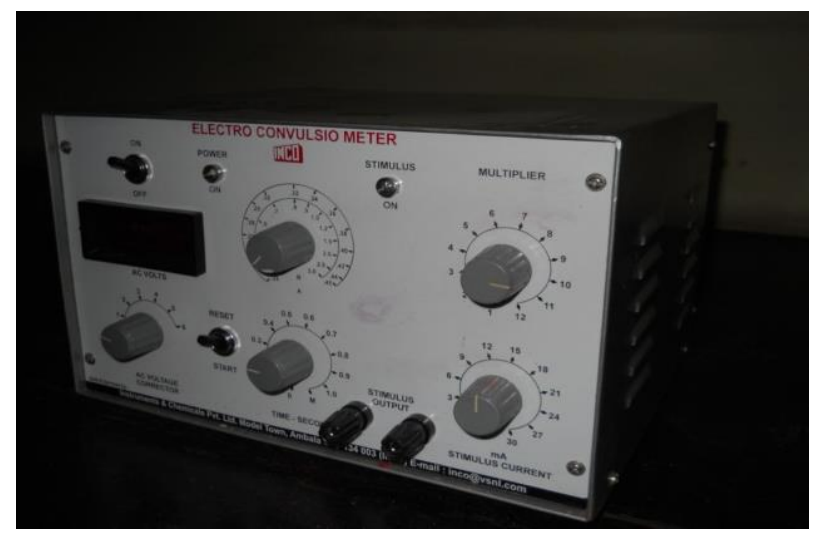

Figure 1: Electroconvulsiometer.

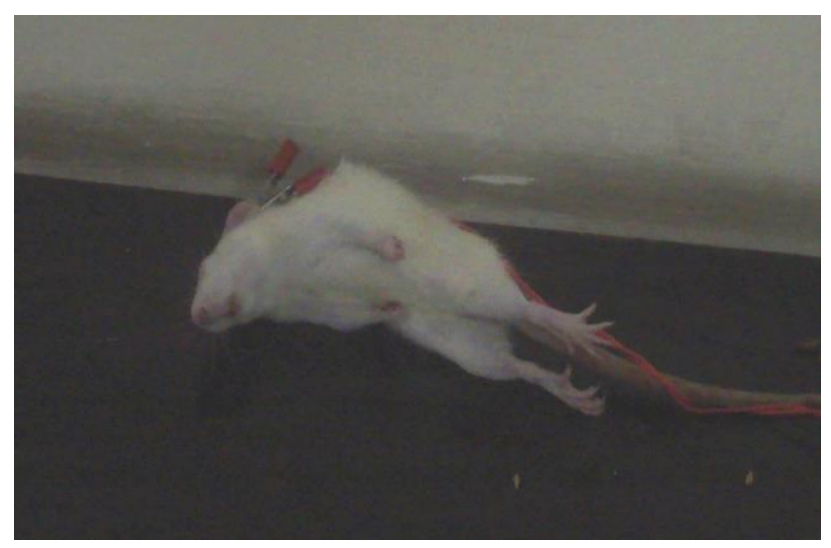

Figure 2: Tonic hind limb extension phase. 


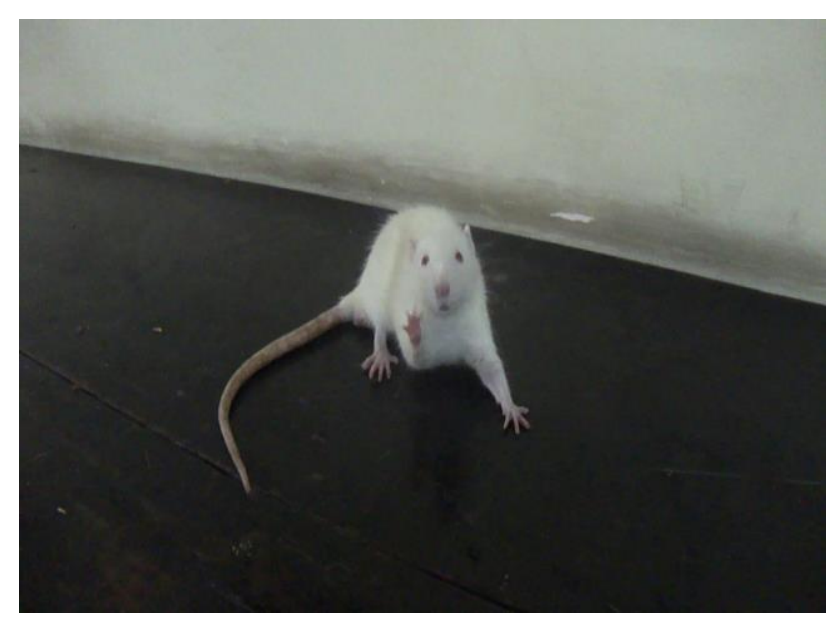

Figure 3: Clonus phase

The abolition of the hind limb tonic extension is taken as an index of anticonvulsant activity. ${ }^{7}$

\section{Pentylene tetrazole model}

Threshold PTZ seizures in rats and mice have long been considered as a model for absence attacks because of its selective therapeutic response to anti absence seizure drugs. $^{8}$

The PTZ model evaluates the ability of potential antiepileptic agents to prevent CLONIC seizures and may correlate with activity against absence seizures. Activity of a drug in this model may affect GABAergic brain systems, either by enhancing GABA levels or by altering sensitivity of postsynaptic GABA receptors. ${ }^{9}$

\section{Proceure}

In this study, PTZ at a dose of $80 \mathrm{mg} / \mathrm{kg}$ IP (dissolved in Normal saline) was used. PTZ is given 30 minutes after the test drug.

The rats are observed for half an hour after drug administration. Prolongation of duration of seizure latency was taken as an index of protection and indicates efficacy of anticonvulsant activity of the test compound. ${ }^{10}$ The parameters studied in PTZ methods were

- Seizure latency (time taken for onset of seizure)

- Myoclonic Jerk.

- Clonus (Figure 3).

Table 1: MES model.

\begin{tabular}{|c|c|c|c|}
\hline Groups & Drug Administered & Method of evaluation & Observations \\
\hline $\begin{array}{l}\text { Group1 animals } \\
\text { (Control group-1; C1) }\end{array}$ & $\begin{array}{l}0.35 \mathrm{ml} / 100 \mathrm{~g} \text { of normal } \\
\text { saline intraperitoneally }\end{array}$ & $\begin{array}{l}\text { After an interval of } 30 \text { minutes they were } \\
\text { subjected to MES stimulation of } 150 \mathrm{~mA} \text { for } \\
0.2 \text { seconds through transauricular electrodes } \\
\text { by using electroconvulsiometer }\end{array}$ & $\begin{array}{l}\text { The duration } \\
\text { of different } \\
\text { parameters } \\
\text { were noted. }\end{array}$ \\
\hline $\begin{array}{l}\text { Group } 2 \text { animals } \\
\text { (Standard group-1; S1) }\end{array}$ & $\begin{array}{l}\text { Six albino rats received } \\
300 \mathrm{mg} / \mathrm{kg} \text { of Sodium } \\
\text { Valproate in normal saline, } \\
\text { intraperitoneally. }^{11}\end{array}$ & $\begin{array}{l}\text { After an interval of } 30 \text { minutes they were } \\
\text { subjected to MES stimulation of } 150 \mathrm{~mA} \text { for } \\
0.2 \text { seconds through transauricular electrodes } \\
\text { by using electroconvulsiometer }\end{array}$ & $\begin{array}{l}\text { The duration } \\
\text { of different } \\
\text { parameters } \\
\text { were noted. }\end{array}$ \\
\hline $\begin{array}{l}\text { Group } 3 \text { animals } \\
\text { (Test group-1; T1) }\end{array}$ & $\begin{array}{l}\text { Six albino rats received } \\
8.75 \mathrm{mg} / \mathrm{kg} \text { of } \\
\text { Acetazolamide in normal } \\
\text { saline, intraperitoneally. }{ }^{13}\end{array}$ & $\begin{array}{l}\text { After an interval of } 30 \text { minutes they were } \\
\text { subjected to MES stimulation of } 150 \mathrm{~mA} \text { for } \\
0.2 \text { seconds through transauricular electrodes } \\
\text { by using electroconvulsiometer }\end{array}$ & $\begin{array}{l}\text { The duration } \\
\text { of different } \\
\text { parameters } \\
\text { were noted. }\end{array}$ \\
\hline $\begin{array}{l}\text { Group } 4 \text { animals } \\
\text { (Test group-2; T2) }\end{array}$ & $\begin{array}{l}\text { Six albino rats received } \\
17.5 \mathrm{mg} / \mathrm{kg} \text { of } \\
\text { Acetazolamide in normal } \\
\text { saline, intraperitoneally. }{ }^{13}\end{array}$ & $\begin{array}{l}\text { After an interval of } 30 \text { minutes they were } \\
\text { subjected to MES stimulation of } 150 \mathrm{~mA} \text { for } \\
0.2 \text { seconds through transauricular electrodes } \\
\text { by using electroconvulsiometer }\end{array}$ & $\begin{array}{l}\text { The duration } \\
\text { of different } \\
\text { parameters } \\
\text { were noted. }\end{array}$ \\
\hline $\begin{array}{l}\text { Group } 5 \text { animals } \\
\text { (Test group-3; T3) }\end{array}$ & $\begin{array}{l}\text { Six albino rats received } \\
35 \mathrm{mg} / \mathrm{kg} \text { of Acetazolamide } \\
\text { in normal saline, } \\
\text { intraperitoneally. }^{13}\end{array}$ & $\begin{array}{l}\text { After an interval of } 30 \text { minutes they were } \\
\text { subjected to MES stimulation of } 150 \mathrm{~mA} \text { for } \\
0.2 \text { seconds through transauricular electrodes } \\
\text { by using electroconvulsiometer }\end{array}$ & $\begin{array}{l}\text { The duration } \\
\text { of different } \\
\text { parameters } \\
\text { were noted. }\end{array}$ \\
\hline $\begin{array}{l}\text { Group } 6 \text { animals } \\
\text { (Test group-4; T4) }\end{array}$ & $\begin{array}{l}\text { Six albino rats received } \\
8.75 \mathrm{mg} / \mathrm{kg} \text { of } \\
\text { Acetazolamide and } \\
150 \mathrm{mg} / \mathrm{kg} \text { of Sodium } \\
\text { Valproate in normal saline, } \\
\text { intraperitoneally. }\end{array}$ & $\begin{array}{l}\text { After an interval of } 30 \text { minutes they were } \\
\text { subjected to MES stimulation of } 150 \mathrm{~mA} \text { for } \\
0.2 \text { seconds through transauricular electrodes } \\
\text { by using electroconvulsiometer }\end{array}$ & $\begin{array}{l}\text { The duration } \\
\text { of different } \\
\text { parameters } \\
\text { were noted. }\end{array}$ \\
\hline
\end{tabular}


Table 2: Pentylenetetrazole (PTZ) model.

\begin{tabular}{|c|c|c|c|}
\hline Groups & Drug Administered & Method of evaluation & Observations \\
\hline $\begin{array}{l}\text { Group } 7 \text { animals } \\
\text { (Control group-2; C2) }\end{array}$ & $\begin{array}{l}\text { Each rat of this group received } \\
0.35 \mathrm{ml} / 100 \mathrm{~g} \text { of normal saline } \\
\text { intraperitoneally }\end{array}$ & $\begin{array}{l}\text { After an interval of } 30 \text { minutes } \\
\text { pentylenetetrazole (PTZ) } 80 \\
\mathrm{mg} / \mathrm{kg}^{12} \text { body weight was } \\
\text { injected intraperitoneally }\end{array}$ & $\begin{array}{l}\text { The duration of } \\
\text { different parameters } \\
\text { were noted. }\end{array}$ \\
\hline $\begin{array}{l}\text { Group } 8 \text { animals } \\
\text { (Standard group-2; S2) }\end{array}$ & $\begin{array}{l}\text { Six albino rats received } 300 \mathrm{mg} / \mathrm{kg} \text { of } \\
\text { Sodium Valproate in normal saline, } \\
\text { intraperitoneally }\end{array}$ & $\begin{array}{l}\text { After an interval of } 30 \text { minutes } \\
\text { pentylenetetrazole (PTZ) } 80 \\
\mathrm{mg} / \mathrm{kg}^{12} \text { body weight was } \\
\text { injected intraperitoneally }\end{array}$ & $\begin{array}{l}\text { The duration of } \\
\text { different parameters } \\
\text { were noted. }\end{array}$ \\
\hline $\begin{array}{l}\text { Group } 9 \text { animals (Test } \\
\text { group-5; T5) }\end{array}$ & $\begin{array}{l}\text { Six albino rats received } 8.75 \mathrm{mg} / \mathrm{kg} \text { of } \\
\text { Acetazolamide in normal saline } \\
\text { intraperitoneally }\end{array}$ & $\begin{array}{l}\text { After an interval of } 30 \text { minutes } \\
\text { pentylenetetrazole (PTZ) } 80 \\
\mathrm{mg} / \mathrm{kg}^{12} \text { body weight was } \\
\text { injected intraperitoneally }\end{array}$ & $\begin{array}{l}\text { The duration of } \\
\text { different parameters } \\
\text { were noted. }\end{array}$ \\
\hline $\begin{array}{l}\text { Group } 10 \text { animals (Test } \\
\text { group-6; T6) }\end{array}$ & $\begin{array}{l}\text { Six albino rats received } 17.5 \mathrm{mg} / \mathrm{kg} \text { of } \\
\text { Acetazolamide in normal saline, } \\
\text { intraperitoneally }\end{array}$ & $\begin{array}{l}\text { After an interval of } 30 \text { minutes } \\
\text { pentylenetetrazole (PTZ) } 80 \\
\text { mg/kg }{ }^{12} \text { body weight was } \\
\text { injected intraperitoneally }\end{array}$ & $\begin{array}{l}\text { The duration of } \\
\text { different parameters } \\
\text { were noted. }\end{array}$ \\
\hline $\begin{array}{l}\text { Group } 11 \text { animals (Test } \\
\text { group-7; T7) }\end{array}$ & $\begin{array}{l}\text { Six albino rats received } 35 \mathrm{mg} / \mathrm{kg} \text { of } \\
\text { Acetazolamide in normal saline, } \\
\text { intraperitoneally }\end{array}$ & $\begin{array}{l}\text { After an interval of } 30 \text { minutes } \\
\text { pentylenetetrazole (PTZ) } 80 \\
\mathrm{mg} / \mathrm{kg}^{12} \text { body weight was } \\
\text { injected intraperitoneally }\end{array}$ & $\begin{array}{l}\text { The duration of } \\
\text { different parameters } \\
\text { were noted. }\end{array}$ \\
\hline $\begin{array}{l}\text { Group } 12 \text { animals (Test } \\
\text { group-8; T8) }\end{array}$ & $\begin{array}{l}\text { Six albino rats received } 8.75 \mathrm{mg} / \mathrm{kg} \text { of } \\
\text { Acetazolamide and } 150 \mathrm{mg} / \mathrm{kg} \text { of } \\
\text { Sodium Valproate in normal saline, } \\
\text { intraperitoneally }\end{array}$ & $\begin{array}{l}\text { After an interval of } 30 \text { minutes } \\
\text { pentylenetetrazole (PTZ) } 80 \\
\mathrm{mg} / \mathrm{kg}^{12} \text { body weight was } \\
\text { injected intraperitoneally }\end{array}$ & $\begin{array}{l}\text { The duration of } \\
\text { different parameters } \\
\text { were noted. }\end{array}$ \\
\hline
\end{tabular}

\section{RESULTS}

\section{Tonic hind limb flexion}

Table 3 shows the comparison of Tonic Limb Flexion (THLF) duration in seconds among various groups in Maximal Electro Shock Seizure Model.

ANOVA analysis shows statistically significant $(\mathrm{p}<0.0001)$ difference between groups included in the study with respect to the variable (THLF duration) considered in the study.
Post hoc LSD test shows statistically significant difference between:

- Control group vs Standard group ( $\mathrm{p}<0.0001)$

- Control group vs Test group1 (Not significant)

- Control group vs Test group $2(\mathrm{p}<0.0001)$

- Control group vs Test group $3(\mathrm{p}<0.0001)$

- Control group vs Test group $4(\mathrm{p}<0.0001)$

- $\quad$ Standard group vs Test group $4(\mathrm{p}=0.03)$

- $\quad$ Test group 1 vs Test group $4(\mathrm{p}=0.0001)$.

Table 3: Comparison of tonic hind limb flexion (THLF) duration in seconds among various groups in maximal electro shock seizure model.

\begin{tabular}{|c|c|c|c|c|c|c|c|c|c|}
\hline Sl. No. of rats & 1 & 2 & 3 & 4 & 5 & 6 & Mean & SE & $\mathbf{P} *$ \\
\hline Control group & 12.05 & 9.85 & 8.4 & 6.4 & 8.3 & 6.3 & 8.55 & 0.89 & \multirow{6}{*}{$<0.0001$} \\
\hline Standard group & 4.13 & 5.06 & 4.8 & 5.91 & 5.24 & 3.53 & 4.78 & 0.34 & \\
\hline Test group 1 & 6.03 & 6.74 & 7.85 & 4.9 & 6.9 & 5.16 & 6.26 & 0.46 & \\
\hline Test group 2 & 4.63 & 2.62 & 4.85 & 3.75 & 5.04 & 6.37 & 4.54 & 0.52 & \\
\hline Test group 3 & 5.86 & 4.8 & 3.64 & 2.44 & 5.11 & 4.43 & 4.38 & 0.49 & \\
\hline Test group 4 & 2.01 & 1.92 & 1.74 & 2.99 & 3.09 & 1.36 & 2.19 & 0.29 & \\
\hline
\end{tabular}

\section{ANOVA}

Table 4 depicts the mean duration of Tonic Hand Limb Flexion of various groups in Maximal Electroshock Seizure Model.
The mean duration of Tonic Hind Limb Flexion (THLF) in control group was 8.55 seconds. The Acetazolamide at doses of $8.75 \mathrm{mg} / \mathrm{kg}$ reduced the duration of THLF to $6.26 \mathrm{sec}$ which was statistically not significant when 
compared to control group. The Acetazolamide at doses of $17.5 \mathrm{mg} / \mathrm{kg}$ and $35 \mathrm{mg} / \mathrm{kg}$ reduced the duration of THLF to $4.54 \mathrm{sec}$ and $4.38 \mathrm{sec}$ respectively, which were statistically significant when compared to control group. The Acz at doses of $8.75 \mathrm{mg} / \mathrm{kg}$ along with Sodium valproate at the dose of $150 \mathrm{mg} / \mathrm{kg}$ reduced the duration of THLF to $2.19 \mathrm{sec}$, which was statistically significant when compared to control group. The standard drug, sodium valproate reduced the duration of THLF to $3.8 \mathrm{sec}$. The Acetazolamide at dose of $8.75 \mathrm{mg} / \mathrm{kg}$ along with Sodium valproate at dose of $150 \mathrm{mg} / \mathrm{kg}$ reduced the duration of THLF to $2.19 \mathrm{sec}$, which was statistically significant when compared to standard group.

Table 4: comparison of tonic hind limb extension (THLE) duration in seconds among various groups in maximal electro shock seizure model.

\begin{tabular}{|llllllllll|}
\hline SI. No. of rats & $\mathbf{1}$ & $\mathbf{2}$ & $\mathbf{3}$ & $\mathbf{4}$ & $\mathbf{5}$ & $\mathbf{6}$ & Mean & SE & P * \\
\hline Control group & 13.18 & 9.18 & 17.83 & 14.06 & 16.37 & 10.23 & 13.48 & 1.38 \\
\hline Standard group & $\#$ & $\#$ & $\#$ & $\#$ & $\#$ & $\#$ & & \\
\hline Test group 1 & 11.43 & 10.18 & 14.55 & 11.68 & 12.79 & 12.11 & 12.12 & 0.60 \\
\hline Test group 2 & 8.33 & $\#$ & $\#$ & $\#$ & 7.62 & 3.39 & 3.22 & 1.60 \\
\hline Test group 3 & 7.48 & $\#$ & 7.96 & $\#$ & $\#$ & $\#$ & 2.57 & 1.63 \\
\hline Test group 4 & $\#$ & $\#$ & $\#$ & $\#$ & $\#$ & $\#$ & & \\
\hline
\end{tabular}

*ANOVA, Note: \# - THLE completely abolished

Table 4 shows the comparison and mean duration of Tonic Hind Limb Extension (THLE) duration is seconds among various groups in Maximal Electro Seizure Model respectively. On post hoc test: Control group vs Test group 1(not significant).

The mean duration of Tonic Hind Limb Extension (THLE) in control group was 13.48 seconds. The acetazolamide at doses of $8.75 \mathrm{mg} / \mathrm{kg}$ reduced the duration of Tonic Hind Limb Extension to $12.12 \mathrm{sec}$, which was statistically not significant. The acetazolamide at doses of $17.5 \mathrm{mg} / \mathrm{kg}$ and $35 \mathrm{mg} / \mathrm{kg}$ abolished the THLE phase in $50 \%$ and $66.66 \%$ of the animal respectively. The Acetazolamide dose of $8.75 \mathrm{mg} / \mathrm{kg}$ along with Sodium valproate at dose of $150 \mathrm{mg} / \mathrm{kg}$ abolished the THLE phase in $100 \%$ of animals. The standard drug, sodium valproate abolished the THLE phase in $100 \%$ of animals.

\section{Clonus}

Table 5 show the Comparison of Clonus duration and mean clonus duration in seconds among various groups in Maximal Electro Shock Seizure Model. Post hoc LSD test shows statistically significant difference between:
- Control group vs Standard group ( $\mathrm{p}<0.0001)$

- Control group vs Test group 1 (Not significant)

- Control group vs Test group $2(\mathrm{p}=0.005)$

- Control group vs Test group $3(<0.0001)$

- Control group vs Test group $4(<0.0001)$

- $\quad$ Standard group vs Test group $4(\mathrm{p}=0.04)$

- $\quad$ Test group 1 vs Test group $4(\mathrm{p}<0.0001)$

- $\quad$ Test group 2 vs Test group $4(\mathrm{p}=0.001)$

- $\quad$ Test group 3 vs Test group $4(\mathrm{p}=0.02)$.

The mean Clonus duration in control group was 17.18seconds. The Acetazolamide at doses of $8.75 \mathrm{mg} / \mathrm{kg}$, reduced the Clonus duration to $12.77 \mathrm{sec}$ which was statistically not significant when compared to control group. The Acetazolamide at doses of $17.5 \mathrm{mg} / \mathrm{kg}$ and $35 \mathrm{mg} / \mathrm{kg}$ reduced the Clonus duration to $10.98 \mathrm{sec}$ and $9.49 \mathrm{sec}$ respectively, which was statistically significant when compared to control group. The standard drug, sodium valproate reduced the duration of clonus to $9.19 \mathrm{sec}$. The Acetazolamide at dose of $8.75 \mathrm{mg} / \mathrm{kg}$ along with Sodium Valproate at dose of $150 \mathrm{mg} / \mathrm{kg}$ reduced the duration of clonus to $4.08 \mathrm{sec}$, which was statistically significant when compared to standard group.

Table 5: Comparison of clonus duration in seconds among various groups in maximal electro shock seizure model.

\begin{tabular}{|lllllllll|l|}
\hline \hline Sl. No. of rats & $\mathbf{1}$ & $\mathbf{2}$ & $\mathbf{3}$ & $\mathbf{4}$ & $\mathbf{5}$ & $\mathbf{6}$ & Mean & SE & P * \\
\hline Control group & 23.02 & 13.85 & 17.07 & 10.78 & 17.11 & 21.26 & 17.18 & 1.85 \\
\hline Standard group & 10.15 & 8.23 & 9.83 & 6.61 & 10.72 & 9.61 & 9.19 & 0.62 \\
\hline Test group 1 & 15.49 & 14.2 & 15.53 & 11.61 & 9.09 & 10.62 & 12.77 & 1.10 \\
\hline Test group 2 & 12.81 & 10.44 & 15.58 & 9.23 & 8.81 & 9.01 & 10.98 & 1.10 \\
\hline Test group 3 & 9.88 & 10.43 & 12.33 & 7.05 & 8.42 & 8.82 & 9.49 & .745 \\
\hline Test group 4 & 2.11 & 4.09 & 4.34 & 3.01 & 5.23 & 5.67 & 4.08 & 0.55 \\
\hline
\end{tabular}

*ANOVA 


\section{Stupor}

Comparison of Stupor duration and mean stupor duration in seconds among various groups in Maximal Electro Shock Seizure Model has been shows in Table 6 respectively. Post hoc LSD test shows statistically significant difference between

- Control group vs Standard group ( $\mathrm{p}=0.007)$

- Control group vs Test group 1 (Not significant)

- Control group vs Test group $2(\mathrm{p}=0.002)$

- Control group vs Test group $3(\mathrm{p}=0.016)$

- Control group vs Test group $4(<0.0001)$

- Standard group vs Test group 4(Not significant)

- $\quad$ Test group 1 vs Test group $4(\mathrm{p}=0.02)$.
The mean Stupor duration in control group was 125.12 seconds. Acetazolamide at doses of $8.75 \mathrm{mg} / \mathrm{kg}$, reduced the stupor duration of to $97.90 \mathrm{sec}$ which was statistically not significant when compared to control group. The Acetazolamide at doses of $17.5 \mathrm{mg} / \mathrm{kg}$ and $35 \mathrm{mg} / \mathrm{kg}$ reduced the stupor duration to $56.54 \mathrm{sec}$ and $69.74 \mathrm{sec}$ respectively, which was statistically significant when compared to control group. The standard drug, sodium valproate reduced the duration of stupor to $65.22 \mathrm{sec}$.

The Acetazolamide at dose of $8.75 \mathrm{mg} / \mathrm{kg}$ along with Sodium Valproate at dose of $150 \mathrm{mg} / \mathrm{kg}$ reduced the duration of stupor to $43.65 \mathrm{sec}$, which was statistically not significant when compared to standard group.

Table 6: Comparison of stupor duration in seconds among various groups in maximal electro shock seizure model.

\begin{tabular}{|lllllllll|}
\hline SI. No. of rats & $\mathbf{1}$ & $\mathbf{2}$ & $\mathbf{3}$ & $\mathbf{4}$ & $\mathbf{5}$ & $\mathbf{6}$ & Mean & SE \\
\hline Control group & 160.18 & 151.87 & 99.9 & 132.63 & 102.23 & 103.89 & 125.12 & 10.97 \\
\hline Standard group & 87.90 & 105.58 & 45.36 & 48.74 & 39.66 & 64.06 & 65.22 & 10.45 \\
\hline Test group 1 & 104.74 & 166.41 & 62 & 84.90 & 71.19 & 98.17 & 97.90 & 15.18 \\
\hline Test group 2 & 59.74 & 39.20 & 59.48 & 67.16 & 62.55 & 51.10 & 56.54 & 4.08 \\
\hline Test group 3 & 52.03 & 82.88 & 67.29 & 119.57 & 50.55 & 46.1 & 69.74 & 11.41 \\
\hline Test group 4 & 30.26 & 79.82 & 20.99 & 48.11 & 60.74 & 21.98 & 43.65 & 9.63 \\
\hline
\end{tabular}

*ANOVA

Table 7: Comparison of postictal depression duration in seconds among various groups in maximal electro shock seizure model.

\begin{tabular}{|c|c|c|c|c|c|c|c|c|c|}
\hline Sl. No. of rats & 1 & 2 & 3 & 4 & 5 & 6 & Mean & SE & $\mathbf{P} *$ \\
\hline Control group & 232.35 & 100.97 & 177.87 & 67.02 & 83.61 & 96.48 & 126.38 & 26.31 & \multirow{6}{*}{$<0.001$} \\
\hline Standard group & 27.07 & 55.23 & 42.73 & 28.85 & 52.71 & 49.27 & 42.64 & 4.96 & \\
\hline Test group 1 & 91.89 & 121.58 & 44.61 & 20.52 & 180.10 & 135.70 & 99.07 & 24.22 & \\
\hline Test group 2 & 93.60 & 79.41 & 60.23 & 32.03 & 41.88 & 43.55 & 50.11 & 7.20 & \\
\hline Test group 3 & 82.95 & 66 & 50.96 & 66.28 & 20.55 & 57.23 & 45.66 & 7.38 & \\
\hline Test group 4 & 20.78 & 27.33 & 36.95 & 19.78 & 40.31 & 32.39 & 29.59 & 3.44 & \\
\hline
\end{tabular}

*ANOVA

Table 8: Showing percentage protection in tonic hind limb extension among various treatment groups in maximal electroshock seizure model.

\begin{tabular}{|ll|}
\hline Treatment Groups & Percentage protection \\
\hline Standard Group & $100 \%$ \\
\hline Test Group 1 & Nil \\
\hline Test Group 2 & $50 \%$ \\
\hline Test Group 3 & $66.66 \%$ \\
\hline Test Group 4 & $100 \%$ \\
\hline
\end{tabular}

\section{Postictal depression}

Table 7 shows the comparison of Postictal depression duration in seconds shows the mean postictal depression in seconds among various groups in Maximal Electro Shock Seizure Model. ANOVA analysis shows statistically significant $(<0.001)$ difference between groups included in the study with respect to the variable (Postictal Depression duration) considered in the study. Post hoc LSD test shows statistically significant difference between.

- Control group vs Standard group $(\mathrm{p}=0.01)$

- Control group vs Test group 1 (Not significant)

- Control group vs Test group $2(\mathrm{p}=0.02)$

- Control group vs Test group $3(\mathrm{p}=0.01)$

- Control group vs Test group $4(\mathrm{p}=0.002)$

- Standard group vs Test group 4 (Not significant).

The mean Postictal Depression duration in control group was 126.38seconds. The Acetazolamide at doses of $8.75 \mathrm{mg} / \mathrm{kg}$, reduced the postictal depression duration to $99.07 \mathrm{sec}$ which was statistically not significant when compared to control group. The Acetazolamide at doses of $17.5 \mathrm{mg} / \mathrm{kg}$ and $35 \mathrm{mg} / \mathrm{kg}$ reduced the Postictal Depression 
duration of to $50.11 \mathrm{sec}$ and $45.66 \mathrm{sec}$ respectively, which was statistically significant when compared to control group. The standard drug, sodium valproate reduced the duration of Postictal Depression to $42.64 \mathrm{sec}$. The acetazolamide at dose of $8.75 \mathrm{mg} / \mathrm{kg}$ along with sodium valproate at dose of $150 \mathrm{mg} / \mathrm{kg}$ reduced the duration of Postictal Depression to $29.59 \mathrm{sec}$, which was statistically not significant when compared to standard group. The percentage protection in Tonic Hand Limb Extension among various treatment groups is listed in Table 8.

\section{Seizure latency}

Comparison of seizure latency duration (seconds) of various groups in the pentylenetertazole model has been shows in Table 9. ANOVA analysis shows statistically significant $(p<0.0001)$ difference between groups included in the study with respect to the variable (Seizure Latency duration) considered in the study. Post hoc LSD test of seizure latency duration in seconds among various groups in Pentylene Tetrazole Model (Table 9) shows statistically significant difference between
- Control group vs Standard group ( $\mathrm{p}<0.001)$

- Control group vs Test group 5 (Not significant)

- Control group vs Test group $6(\mathrm{p}=0.02)$

- Control group vs Test group $7(\mathrm{p}=0.018)$

- Control group vs Test group 8 ( $\mathrm{p}<0.0001)$

- Standard group vs Test group 8 (Not significant)

- Test group 5 vs Test group $8(<0.0001)$

- Test group 6 vs Test group $8(\mathrm{p}=0.006)$

- Test group 7 vs Test group $8(\mathrm{p}=0.007)$.

In control group, there was a mean seizure latency of $142.33 \mathrm{sec}$, following PTZ injection. At the dose of $8.75 \mathrm{mg} / \mathrm{kg}$, the seizure latency was $220.50 \mathrm{sec}$, which was statistically not significant. Whereas, at the dose of $17.5 \mathrm{mg} / \mathrm{kg}$ and $35 \mathrm{mg} / \mathrm{kg}$ the seizure latency was $277.33 \mathrm{sec}$ and $281.00 \mathrm{sec}$ respectively, which was statistically significant, when compared to control group. The standard, sodium valproate produced a mean seizure latency of $329.67 \mathrm{sec}$. The Acetazolamide at dose of $8.75 \mathrm{mg} / \mathrm{kg}$ along with Sodium Valproate at dose of $150 \mathrm{mg} / \mathrm{kg}$ the seizure latency was $432.83 \mathrm{sec}$, which was statistically not significant when compared to standard group.

Table 9: Comparison of seizure latency duration in seconds among various groups in pentylene tetrazole model.

\begin{tabular}{|c|c|c|c|c|c|c|c|c|c|}
\hline Sl. No. of rats & 1 & 2 & 3 & 4 & 5 & 6 & Mean & $\mathbf{S E}$ & $\mathbf{P} *$ \\
\hline Control group & 161 & 189 & 102 & 151 & 103 & 148 & 142.33 & 13.91 & \multirow{6}{*}{$<0.0001$} \\
\hline Standard group & 335 & 494 & 173 & 351 & 382 & 243 & 329.67 & 45.56 & \\
\hline Test group 5 & 193 & 247 & 201 & 251 & 174 & 257 & 220.50 & 14.44 & \\
\hline Test group 6 & 287 & 306 & 357 & 249 & 263 & 202 & 277.33 & 21.56 & \\
\hline Test group 7 & 254 & 366 & 200 & 310 & 233 & 323 & 281.00 & 25.44 & \\
\hline Test group 8 & 390 & 525 & 423 & 493 & 451 & 315 & 432.83 & 30.69 & \\
\hline
\end{tabular}

Table 10: Comparison of clonus latency in seconds among various groups in pentylene tetrazole model.

\begin{tabular}{|c|c|c|c|c|c|c|c|c|c|}
\hline Sl. No. of rats & 1 & 2 & 3 & 4 & 5 & 6 & Mean & SE & $\mathbf{P} *$ \\
\hline Control group & 249 & 225 & 116 & 267 & 157 & 276 & 215.00 & 26.36 & \multirow{6}{*}{$<0.0001$} \\
\hline Standard group & $\#$ & $\#$ & $\#$ & $\#$ & $\#$ & $\#$ & & & \\
\hline Test group 5 & 203 & 277 & 208 & 276 & 180 & 265 & 234.83 & 17.43 & \\
\hline Test group 6 & 406 & 367 & 391 & 302 & 283 & 422 & 361.83 & 23.26 & \\
\hline Test group 7 & 473 & 502 & 436 & 398 & 307 & 451 & 427.83 & 28.07 & \\
\hline Test group 8 & \# & $\#$ & $\#$ & \# & \# & $\#$ & & & \\
\hline
\end{tabular}

*ANOVA, Note: \# - Abolition of clonus

\section{Clonus latency}

Table 10 depicts the omparison of Clonus latency (seconds) and the mean clonus latency (seconds) among various groups in Pentylene Tetrazole Model respectively.

In control group, there was a mean delay in Clonus of $215 \mathrm{sec}$, following PTZ injection. At the dose of $8.75 \mathrm{mg} / \mathrm{kg}$, the delay in Clonus was $234.83 \mathrm{sec}$, which was statistically not significant, when compared to control group. Whereas, at the dose of $17.5 \mathrm{mg} / \mathrm{kg}$ and $35 \mathrm{mg} / \mathrm{kg}$ the delay in Clonus was $361.83 \mathrm{sec}$ and $427.83 \mathrm{sec}$ respectively, which was statistically significant, when compared to control group.

The Acetazolamide at dose of $8.75 \mathrm{mg} / \mathrm{kg}$ along with Sodium Valproate at dose of $150 \mathrm{mg} / \mathrm{kg}$ abolished the clonus in $100 \%$ of animals. The standard drug, sodium valproate abolished the clonus in $100 \%$ of animals.

Percentage Protection in Seizure Latency among various treatment group in Pentylenetetrazole Model has been listed in Table 11. 


\section{Table 11: Showing percentage protection in seizure latency among various treatment group in pentylenetetrazole model.}

\begin{tabular}{|ll|}
\hline Treatment Groups & Percentage protection \\
\hline Standard Group & $100 \%$ \\
\hline Test Group 5 & $66.8 \%$ \\
\hline Test Group 6 & $84.14 \%$ \\
\hline Test Group 7 & $85.25 \%$ \\
\hline Test Group 8 & $131.32 \%$ \\
\hline
\end{tabular}

\section{DISCUSSION}

Significant advances are being made in recent years to treat epilepsy using second-generation drugs. ${ }^{14}$ Polypharmacy is often advocated to $30 \%$ of all epileptic patients for refractory partial or generalized tonic clonic seizures. ${ }^{14}$ However, none of the new drugs fulfill the ultimate goal of drug treatment of epilepsy, i.e. complete control of seizures. ${ }^{16}$ Despite the massive scale of the problem and much research, epilepsy remains poorly understood. Despite more than 20 approved drugs and several nonpharmacological options, up to $30 \%$ of patients are still refractory to treatment. Discovery and development of anti-epileptic drugs has been especially difficult, because of the regulatory issues of satisfactorily proving safety and efficacy, ethical constraints on placebo-controlled trial designs. For this reason, known antiepileptic drugs are used in combination for the treatment. ${ }^{17}$

In this study, the anticonvulsant activity of Acetazolamide was studied against MES and PTZ induced convulsions when it is given alone and upon combination with sodium valproate. The present study demonstrates that abolition of tonic hind limb extension shows that drug poses anticonvulsant activity for MES model and an increase in the seizure threshold, suggesting that the drug possess anticonvulsant property against the PTZ model.

\section{Dose 1-8.75mg/kg body weight}

Analysis of results of 3rd group animals in Maximal Electro Shock (MES) model (Table 3, 4, 5, 6, 7) that received $8.75 \mathrm{mg} / \mathrm{kg}$ of test compound showed a reduction in all phases namely tonic hind limb flexion, tonic hind limb extension, clonus, stupor and postictal depression. Reduction in duration of all phases was statistically not significant when compared to control group. Analysis of results of $9^{\text {th }}$ group animals in Pentylenetetrazole (PTZ) model (Table 9, 10) showed an increase in duration of seizure latency and increase in clonus latency which was statistically not significant, when compared to control group.

\section{Dose 2-17.5mg/kg body weight}

Analysis of results of 4th group animals in MES model (Table $3,4,5,6,7$ ) that received $17.5 \mathrm{mg} / \mathrm{kg}$ of test compound, showed a reduction in all phases. Reduction in duration of tonic hind limb flexion, clonus, stupor and postictal depression were statistically significant, when compared to control group. There was complete abolition of tonic hind limb extension in 3 animals out of 6 animals. $50 \%$ abolition in tonic hind limb extension at this dose was observed.

Analysis of results of 10th group animals in PTZ model (Table 9,10) when compared to control group, showed an increase in duration of seizure latency and increase in clonus latency which was statistically significant.

\section{Dose 3-35mg/kg body weight}

Analysis of results of 5th group animals in MES model (Table $3,4,5,6,7$ ) that received $35 \mathrm{mg} / \mathrm{kg}$ of test compound, showed a reduction in all phases. Reduction in duration of tonic hind limb flexion, clonus, stupor and postictal depression were statistically significant, when compared to control group. There was complete abolition of tonic hind limb extension in 4 animals out of 6 animals. $66.66 \%$ abolition in tonic hind limb extension at this dose was observed.

Analysis of results of 11th group animals in PTZ model (Table 9,10) when compared to control group, showed an increase in duration of seizure latency and increase in clonus latency which were statistically significant. Increase in clonus latency was statistically significant, when compared to group 9.

\section{Dose 4-Acetazolamide $8.75 \mathrm{mg} / \mathrm{kg}+$ Sodium valproate $150 \mathrm{mg} / \mathrm{kg}$ body weight}

Analysis of results of $6^{\text {th }}$ group animals in MES model (Table 3, 4, 5, 6, 7) that received acetazolamide $8.75 \mathrm{mg} / \mathrm{kg}$ body weight and sodium valproate $150 \mathrm{mg} / \mathrm{kg}$ body weight (sub anticonvulsant dose), showed a reduction in all phases. Reduction in duration of tonic hind limb flexion, clonus, stupor and postictal depression were statistically significant, when compared to control group. Reduction in duration of tonic hind limb flexion and clonus was statistically significant, when compared to standard group whereas reduction in stupor and postictal depression was statistically not significant when compared to standard group. Reduction in duration of tonic hind limb flexion was statistically significant, when compared to test group 1. Reduction in duration of clonus was statistically significant, when compared to test group 1, 2 and 3 . Reduction in duration of stupor was statistically significant, when compared to test group 1. There was complete abolition of tonic hind limb extension in all 6 animals. $100 \%$ abolition in tonic hind limb extension at this dose was observed.

Analysis of results of $12^{\text {th }}$ group animals in PTZ model (Table 9, 10) when compared to control group, showed an increase in duration of seizure latency which was statistically significant, whereas increase in duration of seizure latency when compared to standard group was 
statistically not significant. There was increase in duration of seizure latency in $12^{\text {th }}$ group which was statistically significant when compared to group 9, 10 and 11. There was complete abolition of clonus in all 6 animals in this group. i.e. $100 \%$ abolition of the clonus.

Swinyard et al, have considered abolition of hind limb tonic extension as the protective end point against MES induced seizures. ${ }^{18}$ At doses of $8.75 \mathrm{mg} / \mathrm{kg}$ there was no significant anticonvulsant activity. At the dose of $17.5 \mathrm{mg} / \mathrm{kg}$ and $35 \mathrm{mg} / \mathrm{kg}$ tonic hind limb extension was abolished in $50 \%$ and $66.66 \%$ of animals respectively when compared to control. This indicates that the anticonvulsant activity of acetazolamide is less when compared to the standard drug, sodium valproate. The combination of Acetazolamide $(8.75 \mathrm{mg} / \mathrm{kg})$ with sodium valproate $(150 \mathrm{mg} / \mathrm{kg})$ showed significant reduction in all phases of MES model, when compared to the control and standard drug sodium valproate. Most importantly the combination of acetazolamide $(8.75 \mathrm{mg} / \mathrm{kg})$ with sodium valproate $(150 \mathrm{mg} / \mathrm{kg})$ showed complete abolition of tonic hind limb extension in all 6 animals.

According to this study, Sodium valproate $300 \mathrm{mg} / \mathrm{kg}$ showed $100 \%$ protection against tonic hind limb extension. The combination of acetazolamide $8.75 \mathrm{mg} / \mathrm{kg}$ with sodium valproate $150 \mathrm{mg} / \mathrm{kg}$ showed $100 \%$ (Table 8 ) protection against tonic hind limb extension.

The anticonvulsant activity of acetazolamide $8.75 \mathrm{mg} / \mathrm{kg}$ in combination with sodium valproate $150 \mathrm{mg} / \mathrm{kg}$ is comparable and is more significant when compared to sodium valproate $300 \mathrm{mg} / \mathrm{kg}$. The above analysis gives us the result that

- Acetazolamide by itself has significant anticonvulsant activity in the dose of $17.5 \mathrm{mg} / \mathrm{kg}$. But anticonvulsant activity produced by it is not significant when compare to the standard drug sodium valproate in the dose of $300 \mathrm{mg} / \mathrm{kg}$.

- Acetazolamide when combined with sodium valproate showed significant anticonvulsant activity and the combination of these drugs in half of their anticonvulsant dose was found to be more significant when compared to the standard drug alone. This suggests that acetazolamide has potentiated the effect of sodium valproate.

Hence, the test compound may be useful in generalized tonic-clonic seizures (grand mal) or partial epilepsy and the combination drugs may be superior when compared to standard drug alone in generalized tonic-clonic seizures (grand mal) or partial epilepsy. In the Pentylenetetrazole Model, prolongation of seizure latency was taken as protective end point. ${ }^{19}$

At doses of $8.75 \mathrm{mg} / \mathrm{kg}$ of acetazolamide, there was no significant anticonvulsant activity, whereas at $17.5 \mathrm{mg} / \mathrm{kg}$ and $35 \mathrm{mg} / \mathrm{kg}$ there was significant anticonvulsant activity.
Percentage protection offered by sodium Valproate was $100 \%$ against seizure latency. The percentage protection of Acetazolamide at the doses of $8.75 \mathrm{mg} / \mathrm{kg}, 17.5 \mathrm{mg} / \mathrm{kg}$ and $35 \mathrm{mg} / \mathrm{kg}$ were $66.8 \%, 84.14 \%$ and $85.25 \%$ respectively (Table 11). The percentage protection offered by combination acetazolamide $8.75 \mathrm{mg} / \mathrm{kg}$ with sodium valproate $150 \mathrm{mg} / \mathrm{kg}$ was $131.32 \%$ against seizure latency.

This indicates that the anticonvulsant activity of acetazolamide is less when compared to the standard drug, sodium valproate and the anticonvulsant activity of acetazolamide $8.75 \mathrm{mg} / \mathrm{kg}$ with sodium valproate $150 \mathrm{mg} / \mathrm{kg}$ is comparable and more significant when compared to standard drug alone. The above analysis gives us the result that

- Acetazolamide by itself has significant anticonvulsant activity in the dose of $17.5 \mathrm{mg} / \mathrm{kg}$. But anticonvulsant activity produced by it is not significant when compared to the standard drug sodium valproate in the dose of $300 \mathrm{mg} / \mathrm{kg}$.

- Acetazolamide when combined with sodium valproate showed significant anticonvulsant activity and the combination of these drugs in half of their anticonvulsant dose was found to be more significant when compared to the standard drug alone. This suggests that acetazolamide has potentiated the effect of sodium valproate. Hence, the test compound may be useful in absence seizures (petit mal epilepsy) and the combination drugs may be superior when compared to standard drug alone in absence seizures (petit mal epilepsy).

All the rats recovered following MES test and PTZ model. No deaths were recorded. Control group animals (which received normal saline) were not protected against both MES and PTZ models.

Funding: No funding sources Conflict of interest: None declared

Ethical approval: The study was approved by the Institutional Ethics Committee

\section{REFERENCES}

1. Daniel H. Lowenstein. Seizures and epilepsy. Harrisons Principles of Internal Medicine, $17^{\text {th }}$ Ed. Mc Graw Hill; 2009:2498-2513.

2. Satoskar RS, Bhendarkar SD, Rege NN. Pharmacology and Pharmacotherapeutics. 19 $19^{\text {th }}$ Ed. Popular Prakashan; 2005:122-140.

3. Desai CK. Comparative evaluation of anticonvulsant activity of calcium channel blockers in experimental animals. Indian J Exp Biol. 1995;33:931-34.

4. La Roche SM, Helmers SL. The new antiepileptic drugs. JAMA. 2004;291(5):605.

5. White HS. Preclinical development of antiepileptic drugs: Past, present and future directions. Epilepsia. 2003;44(7):2-8. 
6. Woodbury L.A and V.D Davenport. Archives International pharmacodynamic and therapie. 1952;92:97-107.

7. Castel-Branco MM, Alves GL, Figueiredo IV, Falcão A, Caramona MM. The maximal electroshock seizure (MES) model in the preclinical assessment of potential new antiepileptic drugs. 2009;31(1):101-6.

8. Godman LS, Toman JEP, Swinyard EA. Comparison of Maximal seizures evoked by PTZ and electroshock in mice and their modification by anticonvulsant. $\mathrm{J}$ pharmacy pharmacology. 1953:168-76.

9. Michael A, Roger R, Porter J. Antiepileptic drugs: pharmacological Mechanisms and Clinical efficacy with consideration of promising developmental stage compounds. Pharmacol Rev. 1990;42(3):224.

10. James JEP, James EP, Grey ME. Anticonvulsants In evaluation of drug activities pharmacometrics. Volume I. Laurence DR, Bacharahah ARI (Eds.). London. Academic press;1964:287.

11. Brahmane RI, Wanmali VV, Pathak SS, Salwe KJ. Role of cinnarizine and nifedipine on anticonvulsant effect of sodium valproate and carbamazepine in maximal electroshock and pentylenetetrazole model of seizures in mice. $\mathrm{J}$ pharmacol Pharmacothera. 2010;1(2):78.

12. Rehni AK, Singh N. Reversal of pentylenetetrazoleinduced seizure activity in mice by nickel chloride. Indian J Pharmacol. 2009;41(1):15.
13. Anderson RE, Chiu P, Woodbury DM. mechanism of tolerance to the anticonvulsant effects of acetazolamide in mice: relation to the activity and amount of carbonic anhydrase in brain. Epilepsia. 1989;30(2):208-16.

14. Sabers A, Gram L. Drug treatment of epilepsy in the 1990s-achievements and new developments. Drugs. 1996;52:483-93.

15. Pellock JM. Antiepileptic drug-therapy in the UnitedStates-a review of clinical-studies and unmet needs. Neurology. 1995;45:S17-S24.

16. Loscher, W. New visions in the pharmacology of anticonvulsion. Euro J Pharmacol. 1998;342:1-13.

17. White HS. Preclinical development of antiepileptic drugs: Past, present and future directions. Epilepsia. 2003;44(7):2-8.

18. Swinyard EA, Brown WC,Goodman LSJ. Pharmacol Exp Ther. 1952;106:319-30.

19. Vogel HG, editor. Drug discovery and evaluation: pharmacological assays. $3^{\text {rd }}$ Edi. Springer Science \& Business Media; 2008:673.

Cite this article as: Hemanth Kumar KH, Kishore

MS. Study of anticonvulsant activity of acetazolamide on albino rats and its influence on anticonvulsant activity of sodium valproate. Int $\mathrm{J}$ Basic Clin Pharmacol 2018;7:976-85. 